\title{
Globale helseutfordringer sett fra Norge
}

\author{
Rapporten Komplekse utfordringer krever samarbeid på tvers: En kartlegging av perspektiver fra forsknings- \\ institusjoner og organisasjoner i det norske global helsemiljøet ble i forrige uke lansert i Helsedirektoratet \\ på vegne av Norsk Forum for Global Helseforskning.
}

Påfølgende diskusjoner med aktører fra forskningsmiljø, byråkrati og frivillige organisasjoner viste at tverrfaglighet er en utfordring i det norske global helsemiljøet.

Som en følge av globalisering blir verden stadig mindre. Dette gjelder også for global helse, som i økende grad påvirkes av styringsmekanismer og prioriteringer både innad den globale helsesektoren og utenfor. Et godt eksempel er når vi ser tobakksgiganten Philip Morris jobbe for å utsette EUs tiltak for å gjøre sigaretter mindre attraktive for kvinner og barn. Politikk og beslutninger utenfor helsesektoren kan ha store konsekvenser for folkehelsen, og derfor må helsearbeid tilpasses slik at folkehelsen ivaretas i et landskap med konkurrerende interesser. Internasjonalt skiller Norge seg positivt ut fordi vi har tydelige politiske strategier for global helse, blant annet for å sikre helse i møte med andre interesser.

Sigrun Møgedal diskuterte noen av utfordringene vi møter i et komplekst, globalt helselandskap i en leder publisert i Tidsskriftet tidligere $\mathrm{i}$ år. Hun skriver at på tross av gode intensjoner og tydelige offentlige strategier er det manglende sammenheng mellom penger, kunnskap og politikk innen global helse i Norge. Men global helse i Norge består av flere aktører enn de offisielle myndighetene, og disse vet vi mindre om.

\section{Behov for tverrfaglighet}

Norske strategier for helse og helsepolitikk diskuteres blant leger og helsepersonell hver dag. I en klinisk hverdag samarbeider vi med kolleger med ulik ekspertkompetanse - vi ringer psykiatrisk forvakt for suicidvurdering eller varsler kommunelegen ved mistanke om legionella. Når vi møter slike utfordringer, må vi tenke utover spesialitetene våre. De store globale helseutfordringene er i enda større grad tverrfaglige utfordringer.

Hvordan skal vi bekjempe hjerte- og karsykdommer? Betablokkere og kolesterolsenkende midler er sjelden nok alene. Vi ønsker gjerne å promotere en sunnere livsstil, men oppførsel og vaner er vanskelig å endre, og samfunnet må legge til rette for at de sunne valgene også er de enkleste valgene, for eksempel gjennom byplanlegging, skattlegging av sukker og andre matvarer som påvirker helsen negativt, og gjennom internasjonalt samarbeid, som tobakkskonvensjonen.

\section{Kartlegging av perspektiver}

Gjennom intervjuer med 29 ulike forskningsinstitusjoner og frivillige organisasjoner forsøkte vi å kartlegge motivasjonen for å jobbe med global helse og de ulike formene for samarbeid og incentiv som finnes i tilknytning til slikt arbeid i Norge.

Kartleggingen viser at norske forskningsinstitusjoner innenfor global helse har kompetanse og gode intensjoner. Til tross for enkelte svært gode initiativ for samarbeid, er miljøene ofte små og fragmenterte, noe som kan føre til lite synergi, snevre tilnærminger og arbeid i siloer.

Forskningsagendaen påvirkes, ifølge våre respondenter, både av ytre faktorer som økonomiske incentiver og publiseringsincentiver, og indre faktorer som egeninteresse og engasjement. Sammen med politiske prioriteringer kan dette føre til utfordringer for samarbeid, tverrfaglighet og helhetlige tilnærminger. Det er få møteplasser mellom forskningsmiljøer og frivillige organisasjoner, og sistnevnte opplever utfordringer med å få tilgang til relevant materiale.

Forskningsinstitusjonene bør derfor i større grad formidle og diskutere forskning med beslutningstakere, sivilt samfunn og med hverandre på tvers av disipliner.

I diskusjonene under forrige ukes lansering av rapporten i Helsedirektoratet pekte man på utfordringene innen dagens forsknings- og samarbeidsagenda. Etter diskusjonen rundt «global governance for health» og hvordan globale prosesser påvirker global helse og nasjonalt helsearbeid, ble rapporten lansert.

\section{Veien videre}

Tverrfaglig samarbeid og forskning er ofte populære mål, men kan være utfordrende å få til i praksis. I kartleggingen peker man på at tverrfaglige miljøer ses på som hensiktsmessige for å løse globale helseutfordringer. For å få til dette må de ulike aktørene ta ansvar. Diskusjonen på seminaret pekte på at dette kan fremmes av initiativ fra enkeltindivider, forskningsinstitusjoner eller miljøer. Eksempler kan være opprettelse av felles databaser eller oversikt over prosjekter, e-postlister, et tidsskrift for global helse og felles møteplasser for ulike fagdisipliner.

Vi vil likevel hevde at dette ikke er nokrapporten peker på at organiseringen av dagens forskningssystem kan hindre tverrfaglig samarbeid og tenderer å favorisere smalere problemstillinger. At konkurranse mellom forskere kan hemme samarbeid er
Kristine Husøy Onarheim krionarheim@gmail.com Johanne Helene Iversen

Kristine Husøy Onarheim (f. 1987) er medisinstudent ved Universitet i Bergen, men har for tiden permisjon og er gjesteforsker ved Harvard School of Public Health, Boston.

Johanne Helene Iversen (f. 1987) er medisinstudent ved Universitet i Bergen, men har for tiden permisjon og er gjesteforsker ved Harvard School of Public Health, Boston.

PUBLISERT I BLOGGEN

(b) 11.10 .2013

\section{«Beslutningerutenfor helsesektoren kan ha store konsekvenser for folkehelsen»}

nok ikke et isolert problem for helseforskning, men vi mener det er av særlig betydning for global helse, da folkehelsen ikke kan beskyttes innen helsesektoren alene. Vi mener at midler til bredere tilnærminger må bevilges, i tillegg til at forskningsinstitusjoner må legge til rette for tverrfaglig samarbeid og forskning.

Anne Bergh fra Folkehelseinstituttet oppsummerte seminaret og sa at rapporten kan være et første steg mot bedre koordinering og samarbeid. Som medisinstudenter oppfordrer vi derfor dere med viktige roller i Helse-Norge - enten du er byråkrat på kommune- eller departementsnivå, forsker eller aktivist fra en frivillig organisasjon til å bidra til å ta disse neste stegene for å sikre et norsk global helsemiljø som arbeider med de brede og dyptgripende utfordringene vi møter i en globalisert verden. HelseOmsorg21-prosessen, med mål om å utvikle en nasjonal forsknings- og innovasjonsstrategi for helse- og omsorgsfeltet, er et lovende sted å begynne.

Kommentarer til og diskusjon'er om innlegget finner du på blogg.tidsskriftet.no Vil du blogge, ta kontakt. 